\title{
Comparison of Quadriceps Q-Angle Values of Soccer Players and Wrestlers
}

\author{
Murat Şen ${ }^{1}$, Semra Çetin ${ }^{1}$, Cuma Ece ${ }^{1}$, Alaeddin Aydogan ${ }^{1}$, H.Nedim Çetin ${ }^{1}$ \\ ${ }^{1}$ Sakarya University Physical Education and Sport Faculty, Turkey \\ Correspondence: H.Nedim Çetin, Sakarya University Physical Education and Sport Faculty, Turkey.
}

Received: May 5, 2019 Accepted: May 17, $2019 \quad$ Online Published: May 22, 2019

doi:10.11114/jets.v7i7.4248 URL: https://doi.org/10.11114/jets.v7i7.4248

\begin{abstract}
The aim of this study is to compare according to different positions the mean right and left knee Q angle of footballers and wrestlers. In this study, found the female soccer and wrestlers mean age $20.51 \pm 3.47$ years, height $165.43 \pm 4.82$ $\mathrm{cm}$, weight $58.23 \pm 5.18 \mathrm{~kg}$. Male soccer and wrestlers has with mean age $21.30 \pm 3.45$ years, height $173.28 \pm 5.45 \mathrm{~cm}$, weight $65.66 \pm 5.73 \mathrm{~kg}$. One-way ANOVA, Student $\mathrm{t}$, and Duncan post hoc test were used for statistical analysis. In this study, found that the mean right and left knee $Q$ angles of male athletes were $15.08 \pm 1.79^{\circ}$ and $14.49 \pm 1.82^{\circ}$ for the standing position, $14.26 \pm 1.84^{\circ}$ and $13.29 \pm 1.82^{\circ}$ for the supine position.

The mean right and left knee $\mathrm{Q}$ angles of Female athletes were $18.11 \pm 1.32^{\circ}$ and $17.90 \pm 1.35^{\circ}$ for the standing position, $17.52 \pm 1.36^{\circ}$ and $16.82 \pm 1.29^{\circ}$ for the supine position. In this study, were found abnormal results. The difference between the $\mathrm{Q}$ angle values of footballers and wrestlers was found to be statistically significant ( $<<0.001)$. The $\mathrm{Q}$ angle values for male soccer players were found 15.35 for standing right $Q$ angle and 15.12 degrees for standing left $Q$ angle and same values 14.80 and 13.86 degrees in the male wrestlers. $Q$ angle values for women footballers were found 17.32 decrees for standing right $Q$ angle and 17.22 degrees for standing left $Q$ angle, and same values 18.90 and 18.58 degrees in the women wrestlers. Standing and supine $\mathrm{Q}$ angle values of Wrestlers in both men and women were found to be wider than the $\mathrm{Q}$ angle values of soccer athletes $(\mathrm{p}<0.001)$. The right $\mathrm{Q}$ - angle values of the athletes in the standing and supine position were found higher than the left $\mathrm{Q}$-angle values ( $\mathrm{p}<0.05)$.

Conclusion: The $\mathrm{Q}$ angles were within the normal range for footballers and wrestlers. In standing positions $\mathrm{Q}$ angle is higher than from supine positions $\mathrm{Q}$ angle. Athlete's sex, pelvic width, tibia and femur length and dominant foot may increase the quadriceps $\mathrm{Q}$ angle.
\end{abstract}

Keywords: Q angle, soccer, wrestling

\section{Introduction}

The $\mathrm{Q}$ angle is the angle subtended by the intersection of a line drawn from the anterior superior iliac spine to the Centre of the patella and another line connecting the Centre of the patella to the Centre of the tibia tuberosity (Grelsamer et al.,2005). Q-angle is defined as measure of lower limb alignment that represents the resultant force orientation of the quadriceps muscles acting on the patella in the anterior plane (Himmen and Crossley, 2007). The mean of 15 degrees is accepted as "Q" angle value in sedentary people, 14 degrees for men and 17 degrees for women (Reider, 2001). Normal Q angle is 13 degrees for sedentary males and 18 degrees for sedentary females (Heggannavar et al., 2016). It is thought that when the $\mathrm{Q}$ angle exceeds the limit of 15-20 degrees, this causes disorders in the extensor mechanism of the knee and causes patellofemoral pain with the tendency of patella to slide to the lateral (İmamoğlu et al., 1995; Kishalı et al, 2004). In addition to causing knee injuries, Q angle is also reported to be affected by a great number physical factors and postural defects (Eliöz et al, 2015; Y1lmaz et al., 2017). Kopuz et al., (1995) in a study, was concluded that sports might be effective on the external pelvic measurements. Deformities in the legs; brackets leg, $\mathrm{X}$ leg, asymmetric leg, increased Q angle can be counted. These can indirectly disrupt the aesthetic appearance. This is especially important for women. Although people who perform regular sports may have a more uniform body posture and appearance than sedentary people (Yamak et al., 2018), increased Q angle may have a negative effect. There is a wide variety of parameters on the body image. The positive effect of sports and arts education area is indicated (İmamoğlu and Demirtaş, 2017). It has been stated that even the colors of garments create perceptual differences due to their effects on individuals (Yamaner and İmamoğlu, 2018). For example, clothes can close the shape of the legs. For 
example, white color means pure being, peacefulness and good character. It represents calm, relaxed and inner peace (Imamoglu, 2010; Imamoglu 2011; Imamoglu and Demirtas, 2017). Therefore, normale Q angles of footballers and wrestlers can increase the feeling of good be beautiful indirectly, except for injuries. Change in the $\mathrm{Q}$ angle affects the mechanical knee joint and the knee joint is susceptible to musculoskeletal disorders. In addition, changes in Q angle over time leads to inefficiency mechanical knee extensor mechanism, inhibition and weakness of the quadriceps (Levangie and Norkin, 2011). Any alteration in line that increases Q-angle is thought to increase the lateral force on the patella such that a wider Q-angle increases the lateral pull of the quadriceps femoris muscle on the patella and increase the power patellofemoral disorders (Heidari, 2011).

Tibia and femur length, pelvis with, sex, dominant foot and shape of the feet may affect the Q angle (Kishal et al., 2004). Letafatkar et al. (2013) showed a significant relationship between flat foot deformity and larger Q angle with anterior knee pain and larger Q angle with the flat foot deformities. Ilahi and Kohl, (1998) reported that Q angle and leg length difference of the lower limb are main factors related to injuries caused by overuse. Q angle is responsible for transmitting pressure from pelvis to legs. $Q$ angle has been estimated to be about 10 degrees in male and 15 degrees in female. If this angle deviates from its normal position, in addition to causing disorders in patellofemoral function, it may be a risk factor for ankle injuries (Moghadam et al., 2017). Ghiasi et al., (2009) in on wrestlers study, found malignment lower extremity (i.e. a decrease or an increase in Q-angle which shows genu varum and genu valgum in freestyle wrestlers) was an important factor for knee ligament and meniscus injury. Q angle is measure of the alignment of the quadriceps femoris musculature relative to the alignment of the underlying skeletal structures of the pelvis, femur and tibia. A larger in the $\mathrm{Q}$ angle beyond the normal range is considered indicative of extensor mechanism misalignment. Q angle's high has been associated with was Patellofemoral pain syndrome, knee joint hyper mobility, and patellar instability. It has also been suggested that an abnormal Q-angle may also influence neuromuscular response. In this case is quadriceps reflex response time, an Etiological factor in patella femoral pain syndrome. The role of Q angle has taken into account in assessing lower-extremity injuries in athletes (Fatahi et al., 2017). Women have consistently been found to have larger $\mathrm{Q}$ angles than men. They are more often affected by patellofemoral problems. This is maybe due to an increased pelvic width, femoral neck ante version, or shorter femur length. Some result have showed that Q angles greater than 15 " for men and 20 " for women. This situation is more commonly associated with pathological conditions of the Patellofemoral joint (Emami et al., 2007, Fatahi et al., 2017).

In this study, was to search $\mathrm{Q}$ angle between the soccer athletes and wrestling athletes and to determine the relationship between these parameters.

\section{Method}

The study was conducted on footballers and wrestlers. Participants were between 17 and 26 years of age. Of these, 97 are female ( 55 footballers and 42 wrestlers) and 181 are Male (96 footballers and 85 wrestlers). The right legs of the participants had dominant. Soccer and wrestler ahtletes has no background of lower limp injury or dysfunction. The right and left knee angles of athletes were measured when the knee and hip were in full extension. Measure has been first in the supine and then in the standing positions. Before measurements, the borders of patella, the tibias tuberosity and the anterior superior iliac spine were located by careful handling. A specially modified goniometer which had a shorter arm $10 \mathrm{~cm}$ was used and a longer arm $60 \mathrm{~cm}$. The fulcrum of the goniometer was put down on the center of patella; the longer arm was directed to the anterior superior iliac spine and the shorter arm tibias tuberosity. The Q-angle in degree was measured as the angle formed at the intersection of the two lines (Losina et al., 2013). The participations were instructed to keep Quadriceps muscles and relaxed as possible. Right and left Q angle measurements were recorded in degrees. All measurements were taken by the same person. The diameter measurements were taken by Holtain type anthropometric equipment. The length and circumference measurements were taken by tapeline spaced 1 $\mathrm{mm}$. Differences in Q angles and physical characteristic between male soccer and female soccer athletes, male wrestlers and female wrestling athletes were determined using one-way ANOVA and Duncan post hoc. According sex is comparisons between athletes were made using Student's t- test. Correlation coefficients were see to examine the relationship between $\mathrm{Q}$ angle and Physical characteristic of athletes. The level of significance was at $\mathrm{p}<0.001$ and $\mathrm{p}<0.005$.

\section{Results}

In table 1, comparison of physical characteristics' and Q angles of male and female soccer and wrestling athletes are shown. In table 2, comparison of physical characteristics and $Q$ angles of male and female athletes are shown. In table 3, comparison of right and left $\mathrm{Q}$ angles of all Athletes are shown. In Table 4, are shown the correlation coefficients between Q Angles and Physical Characteristics of Athletes. 
Table 1. Comparison of physical characteristics' and Q angles of soccer and wrestling athletes

\begin{tabular}{|c|c|c|c|c|c|c|}
\hline Variables & $\begin{array}{l}\text { Male soccer } \\
(\mathrm{n}=96) \\
(\mathrm{x} \pm \mathrm{sd})\end{array}$ & $\begin{array}{l}\text { Female soccer } \\
(\mathrm{n}=55) \\
(\mathrm{x} \pm \mathrm{sd})\end{array}$ & $\begin{array}{l}\text { Male wrestling } \\
(\mathrm{n}=85) \\
(\mathrm{x} \pm \mathrm{sd})\end{array}$ & 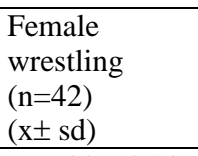 & $\mathrm{F}$ & $\begin{array}{l}\text { Summary } \\
\text { Duncan test }\end{array}$ \\
\hline $\begin{array}{l}\begin{array}{l}\text { Body height } \\
(\mathrm{cm})\end{array}\end{array}$ & \begin{tabular}{ll|}
173.12 & \pm \\
2.31 & \\
\end{tabular} & $165.42 \pm 2.21$ & $173.44 \pm 3.22$ & $165.44 \pm 3.23$ & $74.17 * *$ & $\begin{array}{l}\text { SM>SF, WF } \\
\text { WM>SF, WF }\end{array}$ \\
\hline $\begin{array}{l}\text { Body weight (BW), } \\
\text { (kg) }\end{array}$ & $67.95 \pm 3.42$ & $60.22 \pm 4.52$ & $71.37 \pm 6.17$ & $60.24 \pm 6.07$ & $41.14 * *$ & $\begin{array}{l}\text { SM>SF, WF; } \\
\text { WM>SF, WF, SM }\end{array}$ \\
\hline $\begin{array}{l}\text { Body mass Index } \\
(\text { BMI), }(\mathrm{kg} / \mathrm{m} 2),\end{array}$ & $22,71 \pm 3.10$ & $22,12 \pm 2.17$ & $23,85 \pm 3.90$ & $22,13 \pm 2.78$ & $9,84^{* * *}$ & $\begin{array}{l}\text { SM>SF, WF; } \\
\text { WM>SF, WF, SM } \\
\end{array}$ \\
\hline Age (years) & $20.28 \pm 4.90$ & $35 \pm 2.39$ & $22.32 \pm 3.99$ & $20.67 \pm 3.98$ & $8.51 * *$ & WM $>$ SM, SF,WF \\
\hline $\begin{array}{l}\begin{array}{l}\text { Sports } \\
\text { (years) }\end{array} \\
\text { age }\end{array}$ & $11.21 \pm 3.09$ & $6.79 \pm 3.68$ & $9.72 \pm 3.32$ & $9.45 \pm 3.8$ & $32.37 * *$ & $\begin{array}{l}\mathrm{SF}<\mathrm{WF}, \mathrm{WM}, \mathrm{SM} ; \\
\mathrm{SM}>\mathrm{SF}, \mathrm{WF}, \mathrm{WM}\end{array}$ \\
\hline $\begin{array}{l}\text { Standing right } \\
\text { angle (StRQ), }(0)\end{array}$ & $15.35 \pm 2.02$ & $17.32 \pm 2.11$ & $14.80 \pm 2.10$ & $18.90 \pm 0,11$ & $57.22 * *$ & $\begin{array}{l}\text { WF>WM,SF,S; } \\
\text { SF>WM,SM; } \\
\text { SM>WM }\end{array}$ \\
\hline $\begin{array}{l}\text { Standing left Q angle } \\
\text { (StLQ) (0) }\end{array}$ & $15.12 \pm 2.57$ & $17.22 \pm 2.52$ & $13.86 \pm 2.81$ & $18.58 \pm 2.14$ & $61.62 * *$ & $\begin{array}{l}\text { SM>WM, SF>SM, } \\
\text { WM; } \\
\text { WF>WM, SF, SM }\end{array}$ \\
\hline $\begin{array}{l}\text { Supine right } \mathrm{Q} \text { angle } \\
\text { (SupRQ), (0) }\end{array}$ & $14.82 \pm 1.70$ & $17.01 \pm 1.34$ & $13.69 \pm 1.81$ & $18.03 \pm 1.08$ & $62.49 * *$ & $\begin{array}{l}\text { SM>WM; } \\
\text { SF>WM, SM; } \\
\text { WF>WM, SF,SM }\end{array}$ \\
\hline $\begin{array}{l}\text { Supine left } Q \text { angle } \\
\text { (SupLQ),(0) }\end{array}$ & $14.12 \pm 2.59$ & $16.25 \pm 2.47$ & $12.45 \pm 2.76$ & $17.38 \pm 2.09$ & $77.01 * *$ & $\begin{array}{l}\text { SM>WM; } \\
\text { SF>WM, SM; } \\
\text { WF>WM, SF,SM }\end{array}$ \\
\hline 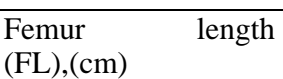 & $48.27 \pm 3.82$ & $48.14 \pm 4.16$ & $47.79 \pm 3.72$ & $45.10 \pm 3.69$ & $9.06 * *$ & $\begin{array}{l}\mathrm{WM}>\mathrm{WF} ; \mathrm{SF}>\mathrm{WF} ; \\
\mathrm{SM}>\mathrm{WF}\end{array}$ \\
\hline $\begin{array}{l}\begin{array}{l}\text { Tibia } \\
\text { (TL), }(\mathrm{cm}\end{array} \\
\text { length } \\
\end{array}$ & $41.38 \pm 3.12$ & $40.38 \pm 3.57$ & $41.62 \pm 3.37$ & $39.03 \pm 3.11$ & $10.30 * *$ & $\begin{array}{l}\text { SM>SF, } \\
\text { WM }>\text { SF, WF }\end{array}$ \\
\hline $\begin{array}{l}\mathrm{Bi} \text { trochanteric } \\
\text { Diameter }(\mathrm{BD}),(\mathrm{cm})\end{array}$ & $28.12 \pm 1.03$ & $27.16 \pm 1.04$ & $29.33 \pm 1.29$ & $28.14 \pm 1.22$ & $14.23 * *$ & $\begin{array}{l}\text { SF>WF, SM, WM; } \\
\text { WF<WM; } \\
\text { SM<WM }\end{array}$ \\
\hline $\begin{array}{l}\text { Femur bi condylar } \\
\text { Diameter }(\mathrm{FD}),(\mathrm{cm})\end{array}$ & $8.33 \pm 0.58$ & $7.67 \pm 0.60$ & $8.61 \pm 0.70$ & $7.97 \pm 0.73$ & $15.12 * *$ & $\begin{array}{l}\text { SM>SF, WF; } \\
\text { WM>SF,WF,SM }\end{array}$ \\
\hline $\begin{array}{l}\text { Thigh circumference } \\
(\mathrm{TC}),(\mathrm{cm})\end{array}$ & $54.56 \pm 4.69$ & $52.31 \pm 4.62$ & $51.37 \pm 4.52$ & $53.22 \pm 4.60$ & $7.56^{* * *}$ & $\begin{array}{l}\text { WF>WM; } \\
\text { SM>WM,SF }\end{array}$ \\
\hline $\begin{array}{l}\text { Calf circumference } \\
(\mathrm{CC}),(\mathrm{cm})\end{array}$ & $35.77 \pm 2.08$ & $33.96 \pm 2.09$ & $36.55 \pm 2.35$ & $34.77 \pm 2.10$ & $12.46^{* *}$ & $\begin{array}{l}\text { SM>SF,WF; } \\
\text { WM }>\text { SF,WF }\end{array}$ \\
\hline
\end{tabular}

${ }^{*} \mathrm{p}<0.05$ and ${ }^{* *} \mathrm{p}<0.001, \mathrm{X}$ : Mean Sd: Standard deviation

SM: Male soccer SF: Female soccer WM: Male wrestling WF: Female wrestling

Table 2. Comparison of physical characteristics and $\mathrm{Q}$ angles of male and female athletes

\begin{tabular}{l|l|l|l}
\hline & $\begin{array}{l}\text { Male }(\mathrm{n}=181) \\
(\mathrm{x} \pm \mathrm{sd})\end{array}$ & $\begin{array}{l}\text { Female }(\mathrm{n}=97) \\
(\mathrm{x} \pm \mathrm{sd})\end{array}$ & $\mathrm{t}$ \\
\hline BH $(\mathrm{cm})$ & $173.28 \pm 5.45$ & $165.43 \pm 4.82$ & $16.52^{* *}$ \\
\hline BW $(\mathrm{kg})$ & $65.66 \pm 5.73$ & $58.23 \pm 5.18$ & $11.02^{* *}$ \\
\hline Age $($ years $)$ & $21.30 \pm 3.45$ & $20.51 \pm 3.47$ & $2.7^{*}$ \\
\hline SA (years) & $10.47 \pm 2.58$ & $8.12 \pm 2.48$ & $3.11^{*}$ \\
\hline StRQ $(0)$ & $15.08 \pm 1.79$ & $18.11 \pm 1.32$ & $-13.14^{* *}$ \\
\hline StLQ $(0)$ & $14.49 \pm 1.82$ & $17.90 \pm 1.35$ & $-11.95^{* *}$ \\
\hline SupRQ $(0)$ & $14.26 \pm 1.84$ & $17.52 \pm 1.36$ & $-12.86^{* *}$ \\
\hline SupLQ $(0)$ & $13.29 \pm 1.82$ & $16.82 \pm 1.29$ & $-13.64^{* *}$ \\
\hline FL $(\mathrm{cm})$ & $48.03 \pm 3.11$ & $46.62 \pm 4.15$ & $3.11^{*}$ \\
\hline TL $(\mathrm{cm}$ & $41.50 \pm 1.23$ & $39.71 \pm 3.98$ & $4.77^{*}$ \\
\hline BD $(\mathrm{cm})$ & $28.73 \pm 1.32$ & $27.65 \pm 2.15$ & $2.40^{*}$ \\
\hline FD $(\mathrm{cm})$ & $8.47 \pm 0.72$ & $7.82 \pm 0.45$ & $5.98^{* *}$ \\
\hline TC $(\mathrm{cm})$ & $52.97 \pm 4.12$ & $52.77 \pm 3.32$ & 0.23 \\
\hline CC $(\mathrm{cm})$ & $36.16 \pm 2.13$ & $34.37 \pm 1.84$ & $4,72^{*}$ \\
\hline
\end{tabular}

$* \mathrm{p}<0.05$ and ${ }^{* *} \mathrm{p}<0.001$ 
Table 3. Comparison of right and left $\mathrm{Q}$ angles of all Athletes $(\mathrm{n}=278)$

\begin{tabular}{l|l|l|l}
\hline Variables & Mean & Standard deviation & $\mathrm{t}$ \\
\cline { 1 - 3 } StRQ $(0)$ & 16.60 & 1.12 & \multirow{2}{*}{$3.41^{*}$} \\
\cline { 1 - 3 } StLQ $(0)$ & 16.20 & 1.09 & \\
\cline { 1 - 3 } SupRQ (0) & 15.88 & 1.13 & \multirow{2}{*}{$3.27^{*}$} \\
\cline { 1 - 3 } SupLQ (0) & 15.05 & 1.44 & \\
\hline
\end{tabular}

*p $<0.05$

Standard deviation

Table 4. The Correlation coefficients between Q Angles and Physical Characteristics of Athletes

\begin{tabular}{l|l|l|l}
\hline Variable & $\mathrm{r}$ & Variable & $\mathrm{r}$ \\
\hline StRQ - TC & $0.1427^{*}$ & StLQ - FL & $-0.1525^{*}$ \\
\hline StLQ - TC & $0.1718^{*}$ & StRQ - TL & $-0.2547^{* *}$ \\
\hline StRQ - CC & $-0.1841^{*}$ & StLQ - TL & $-0.2265^{* *}$ \\
\hline StLQ - CC & $-0.2156^{* *}$ & SupRQ - TL & $-0.2487^{* *}$ \\
\hline SupRQ - CC & $-0.1913^{* *}$ & SupLQ - TL & $-0.2748^{* *}$ \\
\hline StLQ - CC & $-0.2225^{* *}$ & StRQ - BD & $-0.2198^{* *}$ \\
\hline StRQ - StLQ & $0.9412^{* *}$ & StLQ - BD & $-0.2195^{* *}$ \\
\hline SupRQ - SupLQ & $0.9435^{* *}$ & StRQ - BD & $-0.2376^{* *}$ \\
\hline StRQ - SupRQ & $0.9719^{* *}$ & SupLQ - BD & $-0.2839^{* *}$ \\
\hline StLQ - SupLQ & $0.9254^{* *}$ & StRQ - BW & $-0.3164^{* *}$ \\
\hline StLQ - SupRQ & $0.9198^{* *}$ & StLQ - BW & $-0.3342^{* *}$ \\
\hline StLQ - SupLQ & $0.9120^{*}$ & SupRQ - BW & $-0.3360^{* *}$ \\
\hline StRQ - FD & $-0.2849^{* *}$ & SupLQ - BW & $-0.3722^{* *}$ \\
\hline StLQ - FD & $-0.2986^{* *}$ & StRQ - BW & $-0.4368^{*}$ \\
\hline SupRQ - FD & $-0.2852^{* *}$ & StLQ - BH & $-0.4524^{* *}$ \\
\hline SupLQ - FD & $-0.2927^{* *}$ & SupRQ - BH & $-0.4528^{* *}$ \\
\hline StRQ - FL & $-0.1723^{*}$ & SupLQ - BH & $-0.4892^{* *}$ \\
\hline & & & \\
\hline \multirow{0}{*}{ and $* * p<0.001$} & & &
\end{tabular}

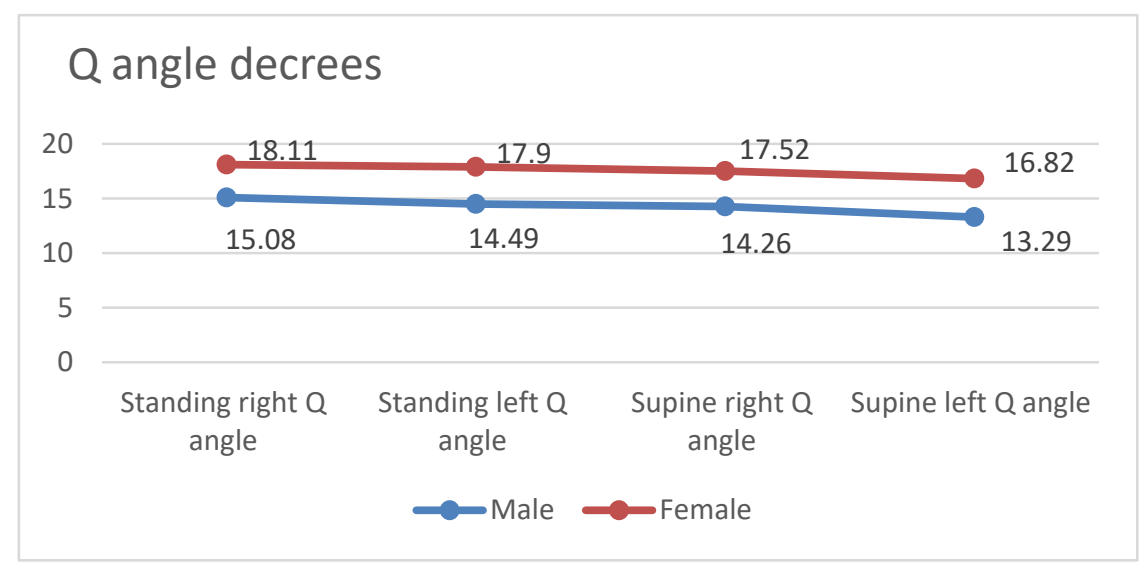

Graphic 1. The right and left $\mathrm{Q}$ angle for the standing and supine position 


\section{Discussion}

In this study, participants were between 17 and 26 years of age. Esmaeili et al., (2015) in a study Q angle greater than 15 degree were defined as high $\mathrm{Q}$ angle and $\mathrm{Q}$ angle 15 degree or less were defined as low $\mathrm{Q}$ angle based on the finding. Normal mean values for the Q-angle are 13.5 degrees in standard healthy subjects between 18 and 35 years of age. Comparatively, Female have a larger mean Q-angle than Male (Females: $15.8^{\circ}$ and Males: $11.2^{\circ}$ ), (Horton and Hall,1989 ). Imamoğlu et al., (1995) in a study, was found the mean Q angle of female students and male students at supine position $15.9^{0}$ and $12.93^{\circ}$. On the other hand $\mathrm{Q}$ angle of female and male students at standing position were $16.92^{\circ}$ and $13.91^{\circ}$ respectively. Kishali et al,(2004) in a study, showed that the mean right and left knee $\mathrm{Q}$ angle of male soccer were $13.82^{\circ}$ and $13.02^{\circ}$ for the supine position, $15.15^{\circ}$ and $14.42^{\circ}$ for standing position. Again, the mean right and left knee $\mathrm{Q}$ angle of female soccer were $16.04^{\circ}$ and 15.44 for the supine position, $16.52^{\circ}$ and $16.08^{\circ}$ for standing position. It were male wrestlers $\mathrm{Q}$ angle $12.69^{\circ}$ and $11.85^{\circ}$ for the supine position, $13.80^{\circ}$ and $12.96^{\circ}$ for standing position. Again, the mean right and left knee $\mathrm{Q}$ angle of female wrestlers were $17.06^{\circ}$ and $16.57^{\circ}$ for the supine position, $18.0^{\circ}$ and $17.4^{\circ} \mathrm{o}$ for standing position.

In this study, the $\mathrm{Q}$ angle values for male soccer players were found 15.35 degrees for standing right $\mathrm{Q}$ angle and 15.12 degrees for standing left $\mathrm{Q}$ angle. The $\mathrm{Q}$ angle values female wrestling athletes were values 14.80 and 13.86 degrees in the male wrestlers. Q angle values for female soccer players were found 17.32 decrees for standing right $\mathrm{Q}$ angle and 17.22 degrees for standing left Q angle. Same Q angle was values 18.90 and 18.58 degrees in the women wrestlers. Q angles value were similar to results of Kishali et al (2004). Standing and supine Q angle values of soccer players in both male and female were found to be little than the Q angle values of wrestling athletes. Mohamed et al., (2017) in a study, found concluded that, flat foot deformity may resulted in increasing Q angle. By in Moghadam et al., (2017) a study was found a significant statistical correlation between increased $Q$ angle with ankle sprain. These normal results in our study indicate that there were no flat foot deformity and sprain in the athletes. In a study the results a significant correlation was found between Q angle and ankle sprain in women who player in the University basketball league in America (Steinberg and Picconatte, 2007). In that case, the athletes are also more vulnerable to sprains.

The literature clearly illustrates that women, on average, have larger Q angles than men do (Livingston and Mandigo, 1999). Teikeira at al.,(2008) showed a bigger normal of $Q$ angle in female when compared to male subjects. Lower $Q$ angles are associated with taller subjects, and, because men are generally taller than women, they tend to have slightly lower $\mathrm{Q}$ angles. Although women have a wider pelvis in the traditional sense, the anterior superior iliac spine in women is no more lateralised than in men (Grelsamer et al., 2005). Hsu et al (1990) the differences ranged from $3^{\circ}$ to $4.6^{\circ}$, a difference which appears insignificant when judged against the inaccuracy of a standard protractor. In Grelsamer study (2005), using a long protractor it found an absolute difference of $2.3^{\circ}$ between men and women. Kishali et al, (2005) in a study, showed that the mean right and left knee Q angle of male athletes were $14.47^{\circ}$ and $13.69^{\circ}$ for the supine position, $13.25^{\circ}$ and $12.44^{\circ}$ for standing position. Again, the mean right and left knee Q angle of female athletes were $17.28^{\circ}$ and $16.90^{\circ}$ for the supine position, $16.57^{\circ}$ and $16.12^{\circ}$ for standing position. In this study, found mean right and left knee Q angles of male athletes $15.08 \pm 1.79^{\circ}$ and $14.49 \pm 1.82^{\circ}$ for the standing position, $14.26 \pm 1.84^{\circ}$ and $13.29 \pm 1.82^{\circ}$ for the supine position, and while those of female athletes were $18.11 \pm 1.32^{\circ}$ and $17.90 \pm 1.35^{\circ}$ for the standing position, $17.52 \pm 1.36^{\circ}$ and $16.82 \pm 1.29^{\circ}$ for the supine position.

When literature was reviewed, it was reported that the changes in $\mathrm{Q}$ angles differed based on the rate and intensity of physical activity and athletes who with more intense training programs showed lower results and it was stated that the results were associated with biomechanical factors such as femur length and pelvic length (Yilmaz et al.,2017). Showing that the mean Q angle on the right side was greater than that on the left and in some others $\mathrm{Q}$ angle was more on the left as compared to the right (Fatahi et al., 2017). In this study, the right Q- angle values of the athletes in the standing and supine position were found higher than the left $\mathrm{Q}$-angle values $(\mathrm{p}<0.05)$.

Many sports medicine experts have linked a wider pelvis to a larger Q (quadriceps) angle, which is the angle at which the femur (upper leg bone) meets the tibia (lower leg bone), (Quinn, 2018). Y1lmaz et al., (2017) in a study, was found that $\mathrm{Q}$ angles of female athletes varied in terms of different branches, while some physical parameters such as sports age, femur length and pelvic width were found to have direct or indirect influences on Q angle. Kishali et al., (2017) in a study, For total athletes, in the supine and standing position the tibia length, body weight and height showed a negative correlation with right and left $\mathrm{Q}$ angles. Femur bi condylar diameter, trochanter diameter and calf circumference showed a negative correlation with $\mathrm{Q}$ angles. In total athletes, while positive correlation was found between thigh circumference and both $\mathrm{Q}$ angles in the standing position, significant correlation was found not in the supine position. In this study, was found for total athletes, in the supine and standing position the tibia length, body weight and height showed a negative correlation with right and left $\mathrm{Q}$ angles $(\mathrm{p}<0.001)$. Femur bi condylar diameter, trochanter diameter and calf circumference showed a negative correlation with $\mathrm{Q}$ angles $(\mathrm{p}<0.001)$. In total athletes, while positive correlation was found between thigh circumference and both $\mathrm{Q}$ angles in the standing position $(\mathrm{p}<0.05)$, significant correlation was 
found not in the supine position ( $p>0.05$ ). It means this result the $\mathrm{Q}$ angle increases with the load increase on Quadriceps femoris muscle, ligaments, genu and patella.

Parallel to study by Domingues et al (2005), found no significant statistic difference between groups for male right knee, male left knee, female right knee and female left knee. In a study, reported the mean difference in Q angle for men in the supine as opposed to the standing position was $0.9^{\circ}$ while the mean difference in $\mathrm{Q}$ angle for women in the supine as opposed to the standing position was 1.2 degrees (Woodlands and Francis, 1992). On average, this angle is three degrees greater in women than in male (17 degrees average for female compared with 14 degrees for male). It is thought that this increased angle places more stress on the knee joint, as well as leading to increased foot pronation in women, (Quinn, 2018).

Activity level of the athletes, their branches, race, and factors affecting muscular power or tendon and joint stability were among the disrupt factors that should be evaluated in future studies along with other effective factors in knee, ankle, and pelvis zone (Moghadam et al., 2017). In this study, was found right and left Q angle average difference for men in the standing position $0.21^{0}$ and if $0.7^{0}$ the supine position. In Females, the right and left $\mathrm{Q}$ angle difference for the standing position was found $0.59^{\circ}$ and if $0.97^{\circ}$ for the supine position (Graphic 1). In this study, the angle of the right foot $\mathrm{Q}$ is higher than the angle of the left foot Q. Soccer players hit the ball with the right foot and keep the right foot of the wrestlers ahead, which means their feet are more dominant and more used. Eliöz et al. (2015) and Y1lmaz et al (2017) in studies, it was stated that high Q angle can be reduced by regular exercise and sports. According to this study, exercise is thought to increase $Q$ angle. We can say that especially during childhood and with heavy exercises may be effective in increasing $\mathrm{Q}$ angle.

\section{Conclusion}

The $\mathrm{Q}$ angles for soccer and wrestling athletes were within the normal range. In addition, in standing positions $\mathrm{Q}$ angle was found higher than from supine positions $Q$ angle. Athlete's sex, tibia and femur length, and pelvic width, dominant foot may increase the quadriceps $Q$ angle.

\section{References}

AlKhouli, M. N., Ghait, A. S., \& Abogazya, A. A. (2017). Relationship Between Flatfoot And Q Angle in Male Secondary School Students. International Journal of Physiotherapy and Research, Int J Physiother Res, 5(6), 2477-81. ISSN 2321-1822. https://doi.org/10.16965/ijpr.2017.232

Domingues, E., Gomes, G., Monteraso, V., \& Tavares, M. (2005). Mensuração do ângulo Q em indivíduos assintomáticos: um estudo comparativo entre os sexos. In III SEMIC Seminário de Iniciação Científica da UNIFENAS, Alfenas: UNIFENAS.

Eliöz, M., Atan, T., Saç, A., \& Yamak, B. (2015). The Investigion of the Relatonship Between Some Physicial Features with Q Angle in Athletes and Sedanteries, Journal of Sports and Performance Researches, 6(1), 58-65. https://doi.org/10.17155/spd.76168

Emami, M. J., Ghahramani, M. H., Abdinejad, F., \& Namazi, H. (2007).Q-angle: an invaluable parameter for evaluation of anterior knee pain. Arch Iran Med, 10, 24-26.

Esmaeili, A. M., Daneshmandi, H., \& Samami, N. (2015).The Study of Relationship Malalignment Knee and Foot with Injury in Professional Sprinters, International Journal of Sport Studies, 5(5), 576-581. www.ijssjournal.com

Fatahi, A., Sadeghi, H., \& Ameli, M. (2017). Relationship Between Q Angle and Knee Injuries Prevalence in Elite Volleyball Players, Advances in Surgical Sciences, 5(4), 45-48. https://doi.org/10.11648/j.ass.20170504.11

Ghiasi, M., Hossein, A. M., \& Reza, R. (2009). Is Q-Angle A Predictor Of Knee Ligament a Menıscus Injury in Elıte Wrestlers? HARAKAT, SPRING, 39, 5-20.

Grelsamer, R. P., Dubey, A., \& Weinstein, C. H. (2005). Men and women have similar Q angles, The Journal of Bone and Joint Surgery, 87-B, 1498-501. https://doi.org/10.1302/0301-620X.87B11.16485

Heggannavar, A., Battula, L., \& Metgud, S. (2016). A Correlation Between Leg-Heel Alignment, Tibial Torsion and Q Angle Amongst Normal, Overweight and Obese Individuals, International Journal Of Physiotherapy And Research, Int J Physiother Res., 4(3), 1530-1534. ISSN 2321-1822. https://doi.org/10.16965/ijpr.2016.125

Heidari B. (2011). Knee Osteoarthritis Prevalence, Risk Factors, Pathogenesis and Features: Part I. Caspian J Intern Med, 2(2), 205-212.

Hinman, R. S., \& Crossley, K. M. (2007). Patellofemoral joint osteoarthritis: an important subgroup of knee osteoarthritis. Rheumatol., 46(7), 1057-1062. https://doi.org/10.1093/rheumatology/kem114

Horton, M. G., \& Hall, T. L. (1989). Quadriceps femoris angle: normal values and relationships with gender and selected skeletal measures. Phys Ther,69:897-901. https://doi.org/10.1093/ptj/69.11.897 
Hsu, R. W., Himeno, S., Coventry, M. B., \& Chao, E. Y. (1990). Normal axial alignment of the lower extremity and load bearing distribution at the knee. Clin Orthop;255: 215-27. https://doi.org/10.1097/00003086-199006000-00029

Huberti, H. H., \& Hayes, W. C. (1994). Patellofemoral contact pressures: the influence of Qangle and tendofemoral contact. / Bone Joint Surg, 66A:715-724. https://doi.org/10.2106/00004623-198466050-00010

Ilahi, O. A., \& Kohl III, H. W. (1998). Lower extremity morphology and alignment and risk of overuse injury. Clinical Journal of Sport Medicine, 8(1), 38-42. https://doi.org/10.1097/00042752-199801000-00009

İmamoğlu, G. (2010). The Effect of Colors on Sportive Performance, Mustafa Kemal University Physical Education and Sports Science, Volume 1, Number 2, pp.40-52

İmamoğlu, G. (2011). The Effect of Colors on Sportive Performance in Football, Ataturk University Physical Education and Sports Science, Volume 7, Number 2,pp. 1-5

İmamoğlu, G., \& Demirtaş, Ö. (2017). Investigation of students' views who receive art and religious training about body image. International Journal of Cultural and Social Studies, 3, 476-483

İmamoğlu, O., Kuru, Ö., Doğan, A. A., \& Tutkun, E. (1995). Mean Quadriceps Angle at Supine and Standing Position of the Physical Education and Sports Departments Students, Karadeniz Medical Journal, 8(3), 126-130.

Kishali, N. F., İmamoglu, O., Burmaoglu, G., Atan, T., \& Yildirim, K. (2004). Q-angle values of elite soccer and taekwondo athletes. The Pain Clinic, 16(1), 27-33. https://doi.org/10.1163/156856904322858675

Kopuz, C., İmamoğlu, O., \& Dabak, Ş. (1995). Analysis of External Pelvic Measurements in Female Sports, Ondokuz Mayls University Health Science, 12 (2), 119-126

Letafatkar, A., Zandi, S., Khodayi, M., \& Vashmesara, J. B. (2013). Flat Foot Deformity, Q Angle and Knee Pain areinterrelated in Wrestlers. J Nov Physiother 3:138. https://doi.org/10.4172/2165-7025.1000138

Levangie, P. K., \& Norkin, C. C. (2011). Joint structure and function: a comprehensive analysis. FA Davis.

Livingston, L. A., \& Mandigo, J. L. (1999). Bilateral Q angle asymmetry and anterior knee pain syndrome, Clin Biomech, 14:7-13. https://doi.org/10.1016/S0268-0033(98)00045-X

Losina, E., Weistein, A M., Reichmann, W. M., Burbine, S. A., Solomon, D. H., \& Daigle, M. E. et al. (2013). Lifetime Risk and Age at Diagnosis of Symptomatic of Knee Osteoarthritis In the US. Arthritis Care Res, 65(5), 703-711. https://doi.org/10.1002/acr.21898

Moghadam. H. Z., Hoseini, S. T., Hashemian, A. M., \& Sharifi, M. D. (2017). The Relation of O Angle and Anthropometric Measures with Ankle Sprain; a Case-control study, Emerg (Tehran). 5(1), e9.

Quinn, E. (2018). Learn About the Q Angle and Potential Injuries in Female Athletes, https://www.verywellfit.com/q-angle-and-injuries-in-women-athletes-3120841

Reider, B. (2001). O exame físico em ortopedia. Rio de Janeiro: Guanabara Koogan, 205 p.

Steinberg, R. J. E., \& Picconatto, W. (2007). Q-angle: Does it Increase Risk of Ankle Sprains in NCAA Division III Women's Basketball?: 1879: Board\# 167 10: 30 AM-10: 30 AM. Medicine \& Science in Sports \& Exercise, 39(5), S318-S9. https://doi.org/10.1249/01.mss.0000274238.97056.16

Teikeira, K. P., Masuyama, N. A., \& Folha, R. A. C. (2008). Ângulo Q e trato iliotibial: um estudo de correlação. Belém: UNAMA, p. 25-66

Woodlands, L. H., \& Francis, R. S. (1992). Parameters and comparisons of the quadriceps angle of collage-aged men and women in the supine and standing positions. Am J Sports Med., 20, 208-211. https://doi.org/10.1177/036354659202000220

Yamak, B., İmamoğlu, O., İslamoğlu, İ., \& Çebi, M. (2018). The effects of exercise on body posture. Turkish Studies Social Sciences, 13(18), 1377-1388. https://doi.org/10.7827/TurkishStudies.13911

Yamaner, F., \& İmamoğlu, G. (2018). Sport performance colors power and effect. Turkish Studies, 13(15), 515-526. https://doi.org/10.7827/TurkishStudies.13602

Yılmaz, A. K., Kabadayı, M., Mayda, M. H., Çavuşoğlu, G., \& Taşmektepligil, M. Y. (2017). Analysis of Q Angle Values of Female Athletes From Different Branches, Science, Movement and Health, XVII(2), 141-146.

\section{Copyrights}

Copyright for this article is retained by the author(s), with first publication rights granted to the journal.

This is an open-access article distributed under the terms and conditions of the Creative Commons Attribution license which permits unrestricted use, distribution, and reproduction in any medium, provided the original work is properly cited. 